\title{
PERILAKU HIDUP SEHAT TENTANG PENCEGAHAN PENYAKIT KECACINGAN DI SDN 03 OLAK KEMANG KOTA JAMBI
}

\author{
Fithriyani' ${ }^{1}$, Rino $\mathrm{M}^{2}$ \\ ${ }^{1,2)}$ Program Studi S1 Keperawatan, Sekolah Tinggi Ilmu Kesehatan Baiturahim Jambi \\ email: fithri.yani25@yahoo.co.id
}

\begin{abstract}
Worm disease is very influential on the health, nutrition and productivity of sufferers. Many diseases are health problems in Indonesia, one of which is worms that are transmitted through the soil. The prevalence of intestinal worms in Indonesia is generally still very high, especially in the disadvantaged population with poor sanitation. the highest incidence of intestinal worms in the Olak Kemang health center was 139 patients and in 2016100 patients, but despite a decline but at the Olak Kemang Public Health Center the highest incidence of worms. While the number of occurrences occurs a lot at the age of 5-9 years, namely 47 patients where the age stage is the age stage of school children. Target The output of this activity identifies the healthy hygienic behavior of children in SDN 03 Olak Kemang with the method of conducting Health Counseling Clean Healthy Lifestyle about helminthiasis. This activity has a positive impact on students to pay more attention to their health in healthy living behaviors for the prevention of helminthiasis in everyday life. Followed by the role of the Olak Kemang Community Health Center to supervise clean living behavior in children in its working area.
\end{abstract}

Keywords: Worm disease; Healthy hygienic behavior

\begin{abstract}
ABSTRAK
Penyakit cacingan sangat berpengaruh pada kesehatan, gizi dan produktifitas penderitanya. Banyak penyakit yang merupakan masalah kesehatan di Indonesia, salah satu diantaranya ialah cacingan yang ditularkan melalui tanah. Prevalensi cacingan di Indonesia pada umumnya masih sangat tinggi, terutama pada golongan penduduk yang kurang mampu dengan sanitasi buruk. angka kejadian cacingan di puskesmas Olak Kemang tertinggi yaitu 139 penderita dan tahun 2016 100 penderita, namun walaupun terjadi penurunan tapi di Puskesmas Olak kemang masing tertinggi angka kejadian cacingannya. Sementara angka kejadian tersebut banyak terjadi pada usia 5-9 tahun yaitu 47 penderita dimana tahap usia tersebut merupakan tahap usia anak sekolah. Target Luaran kegiatan ini mengidentifikasi prilaku hidup bersih sehat anak di SDN 03 Olak kemang dengan metode kegiatan melakukan Penyuluhan Kesehatan Prilaku Hidup Sehat Bersih tentang kecacingan. Kegiatan ini memberikan dampak positif kepada siswi agar lebih memperhatikan kesehatannya dalam perilaku hidup sehat untuk pencegahan penyakit kecacingan dalam kehidupan sehari-hari. Ditindaklanjuti dengan peran puskesmas Olak Kemang melakukan pengawasan perilaku hidup bersih pada anak-anak diwilayah kerjanya.
\end{abstract}

Kata kunci : Penyakit kecacingan;Prilaku Hidup Bersih 


\section{PENDAHULUAN}

Cacingan atau kecacingan merupakan penyakit endemik dan kronik yang diakibatkan oleh cacing parasit. Dengan prevalensi yang tinggi berakibat menurunkan kondisi gizi dan kesehatan masyarakat. Penyakit cacingan sangat berpengaruh pada kesehatan, gizi dan produktifitas penderitanya. Secara ekonomi juga menyebabkan kerugian karena cacing menghisap makanan didalam tubuh manusia, baik berupa karbohidrat dan protein yang menyebabkan menurunnya kualitas sumber daya manusia (Irianto, 2009).

Banyak penyakit yang merupakan masalah kesehatan di Indonesia, salah satu diantaranya ialah cacingan yang ditularkan melalui tanah. Prevalensi cacingan di Indonesia pada umumnya masih sangat tinggi, terutama pada golongan penduduk yang kurang mampu dengan sanitasi buruk (Kemenkes RI, 2012).

Indonesia merupakan salah satu negara endemik Soil Transmitted Helminths dengan jumlah anak usia 1-14 tahun terbanyak ketiga di dunia setelah India dan Nigeria yaitu $7 \%$. Prevalensi cacingan di Indonesia antara 45-65\%, bahkan pada daerah tertentu yang kondisi lingkungannnya buruk bisa mencapai $80 \%$ (Wahyudi, 2012).

Berdasarkan data dari Dinas Kesehatan Kota Jambi, dilihat dari laporan bulanan kejadian penyakit cacingan pada tahun 2015 , angka kejadian cacingan di puskesmas Olak Kemang tertinggi yaitu 139 penderita dan tahun $2016 \quad 100$ penderita, namun walaupun terjadi penurunan tapi di Puskesmas Olak kemang masing tertinggi angka kejadian cacingannya. Sementara angka kejadian tersebut banyak terjadi pada usia 5-9 tahun yaitu 47 penderita dimana tahap usia tersebut merupakan tahap usia anak sekolah.
Usia anak sekolah merupakan usia pada periode ketika anak-anak dianggap mulai bertanggung jawab atas perilakunya sendiri dalam hubungannya dengan orang tua mereka, teman sebaya dan orang lain (Keyla dan Carman, 2015).

Penyebab cacingan pada anak bisa karena adanya sanitasi lingkungan yang kurang terjaga, kebiasaan anak-anak buang air besar sembarangan, tangan yang kotor saat menyentuh makanan yang dapat menyebabkan masuknya telur cacing kedalam tubuh (Proverawati, 2012).

Anak usia sekolah yang kurang menjaga kebersihan dirinya selama dilingkungan luar rumah, rentan terkena penyakit cacingan. Di SDN 03 Olak kemang yang merupakan wilayah kerja Puskesmas Olak Kemang dengan angka kejadian cacingan tertinggi di kota jambi. Menurut pengamatan, murid disana melepas alas kaki ketika bermain di jam istirahat sekolah tanpa mencuci kaki kembali dan kebersihan kuku yang kurang.

\section{TARGET DAN LUARAN}

Target Luaran dalam kegiatan ini adalah Mengidentifikasi perilaku hidup bersih sehat anak di SDN 03 Olak kemang dan memberikan Penyuluhan Kesehatan Perilaku Hidup Sehat Bersih tentang kecacingan.

\section{METODE PELAKSANAAN}

Pengabdian kepada masyarakat ini dilakukan pada bulan Agustus 2017 di SDN 03 Olak Kemang. Adapun tahap pelaksanaan Pengabdian kepada Masyarakat ini melakukan identifikasi permasalahan perilaku hidup bersih penyebab kecacingan pada siswa siswi di SDN 03 Olak Kemang. Metode pelaksanaan kegiatan ini berupa kegiatan penyuluhan kesehatan perilaku hidup bersih sehat tentang kecacingan. 
Materi penyuluhan difokuskan kepada perilaku pencegahan kecacingan sebagai berikut:

\section{Pencegahan Penyakit Cacingan}

a. Biasakan mencuci tangan sebelum makan atau memegang makanan. Gunakan sabun dan bersihkan bagian kuku jemari yang kotor.

b. Biasakan menggunting kuku secara teratur seminggu sekali.

c. Tidak membiasakan diri menggigit kuku jemari tangan atau mengisap jempol.

d. Tidak membiasakan bayi dan anak bermain di tanah.

e. Tidak membuang hajat di kebun, parit, sungai, atau danau. Biasakan buang hajat hanya di jamban.

f. Biasakan membasuh tangan dengan sabun sehabis dari jamban.

g. Biasakan tidak jajan makananyang tidak bertutup atau yang terpegang-pegang tangan.

h. Biasakan makan daging yang sudah benar-benar matang dan bukan yang mentah atau yang setengah matang.

i. Tidak makan keong, ikan, udang, ketam, atau tanaman air secara mentah atau setengah matang.

j. Biasakan berjalan ke mana-mana menggunakan alas kaki

k. Tidak memupuk sayur-mayur dan tanaman dengan tinja manusia.

1. Biasakan makan lalp mentah yang sudah dicuci bersih dengan air mengalir. Bersihkan helai demi helai sayur yang akan dimakan mentahan.

\section{HASIL DAN PEMBAHASAN}

Hasil yang dicapai dalam kegiatan ini antara lain : Pelaksanaan Pengabdian pada masyarakat dimulai dari pengajuan izin pelaksanaan kepada Kepala Sekolah SDN 03 Olak Kemang Kota jambi. Sebelum memberikan penyuluhan siswa diberikan penjelasan tentang kegiatan yang akan dilaksanakan dan meminta persetujuan.
Kemudian pelaksanaan kegiatan penyuluhan kesehatan prilaku hidup bersih sehat tentang kecacingan yang dilaksanakan terhadap murid SDN 03 Olak Kemang. Pelaksanaan kegiatan dilakukan di ruang aula SDN 03 Olak Kemang Kota jambi pada tanggal 10 Agustus 2017.

Evaluasi pelaksanaan Pengabdian kepada masyarakat dibagi menjadi 3 evaluasi yaitu: a. Evaluasi Struktur, Penyuluhan tentang prilaku hidup bersih sehat tentang kecacingan yang berperan sebagai presenter adalah Ns. Fitriyani, S.Kep, M.Kep dan yang berperan sebagai observer adalah Ns. Rino.M, S.Kep, M.Kep. Semua anggota berperan secara baik dan sesuai dengan rencana. Pelaksanaan pengabdian ini dibantu oleh 3 orang mahasiswa yang bertugas sebagai fasilitator dan moderator. b. Evaluasi Proses, Selama proses berlangsung siswa sangat antusias dan aktif dalam berdiskusi. Sebanyak $75 \%$ siswa bertanya terkait dengan materi yang disampaikan. Selama proses berlangsung tidak ada siswa yang keluar masuk ruangan .Selama penyuluhan Presenter mampu berinteraksi dengan baik kepada seluruh siswa.c. Evaluasi Hasil, 80 $\%$ siswa mampu memahami tentang kecacingan ,75\% dari siswa yang hadir mampu menjelaskan kembali tentang penyebab kecacingan, $80 \%$ siswa yang hadir mampu menjelaskan prilaku hidup bersih mencegah kecacingan , 80\% siswa mampu menjelaskan kembali dampak dari penyakit kecacingan.

Rencana Tindak lanjut yang perlu dilakukan untuk pencegahan penyakit kecacingan pada siswa di SDN 03 Olak Kemang ini antara lain : Melakukan koordinasi dengan puskesmas Olak Kemang untuk melakukan kegiatan rutin pencegahan penyakit kecacingan dengan perilaku hidup bersih, melakukan pemeriksaan rutin terhadap anak-anak diwilayah kerja sekitar puskesmas Olak Kemang dan melakukan penelitian terkait dengan prilaku hidup sehat dalam 
pencegahan penyakit kecacingan di wilayah Olak Kemang.

\section{KESIMPULAN DAN SARAN}

\section{Kesimpulan}

Pelaksanaan pengabdian kepada masyarakat khususnya pada siswi SDN 03 Olak Kemang Kota Jambi yang dilakukan oleh dosen STIKes Baiturrahim dan Mahasiswa berjalan dengan baik. Siswi yang hadir sangat antusias dalam bertanya dan menjawab pertanyaan yang diberikan oleh moderator. Kegiatan ini memberikan dampak positif kepada siswi agar lebih memperhatikan kesehatannya dalam perilaku hidup sehat untuk pencegahan penyakit kecacingan dalam kehidupan sehari-hari.

\section{Saran}

a. Bagi Puskesmas Olak Kemang Kota Jambi

Tenaga Kesehatan baik di Puskesmas maupun di PUSTU harus lebih aktif melaksanakan pemberian pendidikan kesehatan kepada anak-anak terkait prilaku hidup bersih tentang pencegahan penyakit kecacingan di wilayah kerja puskesmas.

b. Bagi Insitusi STIKBA Jambi

Pelaksanaan pengabdian masyarakat bagi dosen -dosen STIKBA Jambi lebih menggali kebutuhan masyarakat akan kesehatan dan dapat bermanfaat bagi masyarakat sekitar terutama yang menjadi tempat pengabdian masyarakat.

\section{UCAPAN TERIMAKASIH}

Kegiatan pengabdian masyarakat ini tidak akan berjalan tanpa dukungan dari berbagai pihak. Ucapan terimakasih kepada kepala sekolah SDN 03 Olak Kemang yang bersedia menjadi tempat pelaksanaan kegiatan. Tim pengabdian masyarakat dosen program studi S1 Keperawatan dan mahasiswa tercinta. Dan juga tidak akan lancar pelaksanaan kegiatan ini tanpa bantuan hibah dana dari Sekolah Tinggi Ilmu Kesehatan baiturahim Jambi sebagai penunjang kegiatan pengabdian masyarakat bagi dosen dalam memenuhi tugas dalam tri darma perguruan Tinggi.

\section{DAFTAR PUSTAKA}

Anik,M. 2013. Prilaku Hidup Bersih dan Sehat. Jakarta. Trans Info Media

Irianto, K. 2009. Parasitologi. Bandung.Cv.Yrama idya

Kemenkes Ri. 2012. Pedoman pengendalian Cacingan. Jakarta

Pukesmas Olak kemang. 2016. Data Penderita Penyakit Cacingan tahun 2016. Kota Jambi

Proverawati, A dan E. Rahmawati. 2012. PHBS . Yogyakarta. Nuha Medika

Keyla dan Carman. 2015. Buku ajar Keperawatan dasar Pediatrik. Edisi 2 vol 1.Jakarta. EGC 